\title{
A snapshot into the terrestrial ecosystem of an exceptionally wellpreserved dinosaur (Hadrosauridae) from the Upper Cretaceous of North Dakota, USA
}

ARTICLE in CRETACEOUS RESEARCH · NOVEMBER 2013

Impact Factor: 1.9 D DOI: 10.1016/j.cretres.2013.08.010

CITATIONS

2
READS

83

5 AUTHORS, INCLUDING:

Vivi Vajda

Swedish Museum of Natural History

70 PUBLICATIONS 899 CITATIONS

SEE PROFILE

Antoine Bercovici

Smithsonian Institution

32 PUBLICATIONS 171 CITATIONS

SEE PROFILE

\section{Tyler R. Lyson}

Denver Museum of Nature and Science

37 PUBLICATIONS 476 CITATIONS

SEE PROFILE

Jessamy H. Doman

Yale University

9 PUBLICATIONS 2 CITATIONS

SEE PROFILE 


\title{
A snapshot into the terrestrial ecosystem of an exceptionally well- preserved dinosaur (Hadrosauridae) from the Upper Cretaceous of North Dakota, USA
}

\author{
Vivi Vajda $^{\text {a, } * \text {, Tyler R. Lyson }}{ }^{\text {b, c }}$, Antoine Bercovici ${ }^{\text {, J Jessamy H. Doman }}{ }^{\text {d }}$, \\ Dean A. Pearson ${ }^{\mathrm{e}}$ \\ a Department of Geology, Lund University, Sölvegatan 12, SE-223 62 Lund, Sweden \\ ${ }^{\mathrm{b}}$ Department of Vertebrate Zoology, Smithsonian Institution National Museum of Natural History, 37012, Washington, DC 20013-7012, USA \\ ${ }^{c}$ Marmarth Research Foundation, Marmarth, ND 58643, USA \\ d Department of Anthropology, Yale University, New Haven, CT 06511, USA \\ e Pioneer Trails Regional Museum, Paleontology Dept., 12 First Ave. NE, Bowman, ND 58623, USA
}

\section{A R T I C L E I N F O}

Article history:

Received 9 November 2012

Accepted in revised form 23 August 2013

Available online

\section{Keywords:}

Hell Creek

Maastrichtian

Paleoclimate

Palynology

Hadrosaur

Dinosaur

Swamp

\begin{abstract}
A B S T R A C T
A palynological investigation of sedimentary rocks enclosing an exceptionally well-preserved fossil dinosaur (Hadrosauridae) discovered in the upper part of the Hell Creek Formation in south western North Dakota was conducted in order to document the immediate paleoenvironment of this dinosaur. The specimen, an Edmontosaurus annectens is remarkable in having exceptional three-dimensional preservation of soft tissue around the skeleton, indicating rapid burial. A well-preserved palynological assemblage dominated by fern and bryophyte spores, with lesser gymnosperm and angiosperm pollen was recovered. Sparse fresh-water algae and marine dinoflagellate cysts were also recorded. The palynofacies is dominated by wood fragments, including charcoal, with little amorphous organic matter. The presence of some typical pollen taxa of the Wodehouseia spinata Assemblage Zone including Striatellipollis striatellus, Tricolpites microreticulatus, Leptopecopites pocockii as well as a diverse suite of Aquilapollenites, is fully consistent with a Late Cretaceous (late Maastrichtian) age. The palynoflora indicates a local vegetation composed of a canopy of conifers dominated by Pinaceae and a minor sub-canopy of Taxodium and cycads, as well as an understory of hydrophilous ferns, mosses and herbaceous angiosperms, indicative of a warm and humid climate - an environment where this specific hadrosaur roamed over 66 million years ago.
\end{abstract}

(c) 2013 Elsevier Ltd. All rights reserved.

\section{Introduction}

The Hell Creek Formation represents the uppermost Cretaceous sedimentary unit of central USA, more specifically in North Dakota, South Dakota, and Montana (see papers in Hartman et al., 2002). The sediments of the Hell Creek Formation preserve an abundant fossil fauna, including some of the last non-avian dinosaurs to have roamed the earth (Pearson et al., 2001; Lyson et al., 2012). The nonavian dinosaur fauna present in the Hell Creek Formation disappears at the Cretaceous-Paleogene boundary (e.g. Lyson et al., 2012 and references therein) reflecting the global extinction of species

\footnotetext{
* Corresponding author. Tel.: +46 462224635 .

E-mail address: vivi.vajda@geol.lu.se (V. Vajda).
}

connected to this event where global food webs were disrupted (Vajda et al., 2001, 2004; Ocampo et al., 2006: Chin et al., 2013).

Dinosaur assemblages from the Hell Creek and contemporaneous formations (i.e., Scollard, Willow Creek, North Horn, Frenchman, Lance Creek, Denver, and McRae) of the Western Interior of North America and Canada were dominated by megaherbivores such as Triceratops spp. and Edmontosaurus annectens, together with large carnivores such as Tyrannosaurus rex (Pearson et al., 2002; Sampson and Loewen, 2005; Lyson and Longrich, 2011).

An exceptionally well-preserved "mummified" hadrosaur dinosaur (MRF-03), referred to Edmontosaurus annectens (sensu Campione and Evans, 2011), was discovered in 1999 in a thick sandstone unit within the Upper Cretaceous Hell Creek Formation, northwest of Marmarth, North Dakota (Fig. 1A, B and 2A). The specimen was excavated from a 6 m-thick unit of sandstone representing the lateral accretion of a large point-bar. Soft tissue is 
A

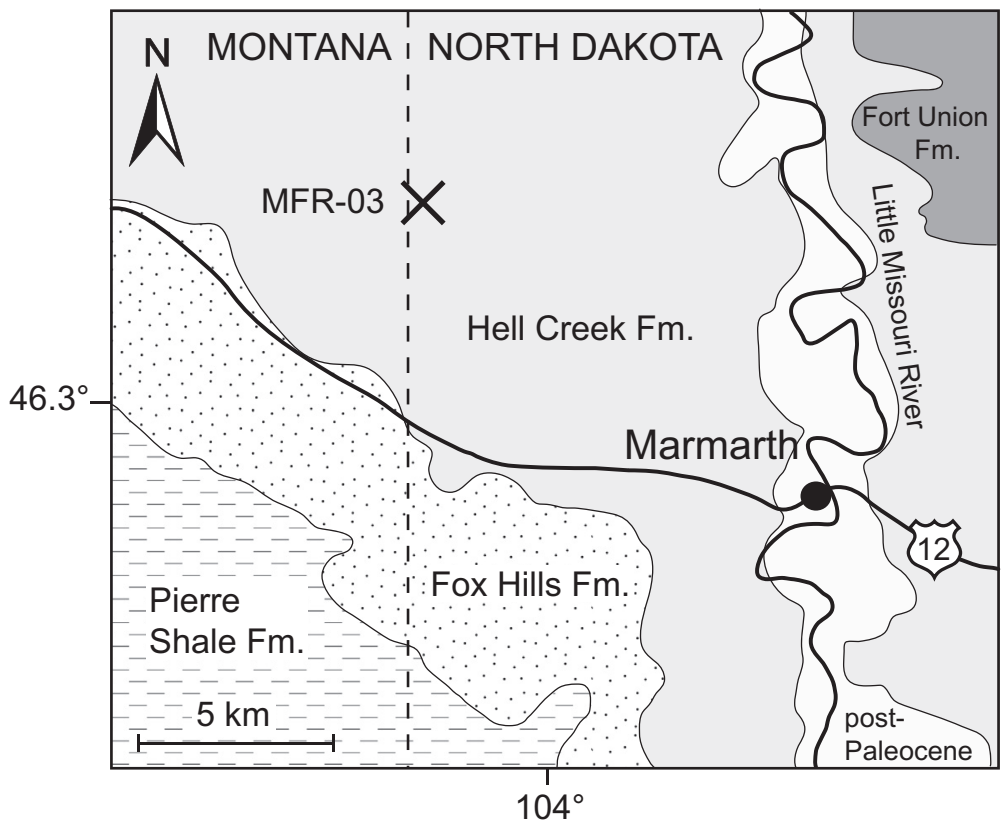

B

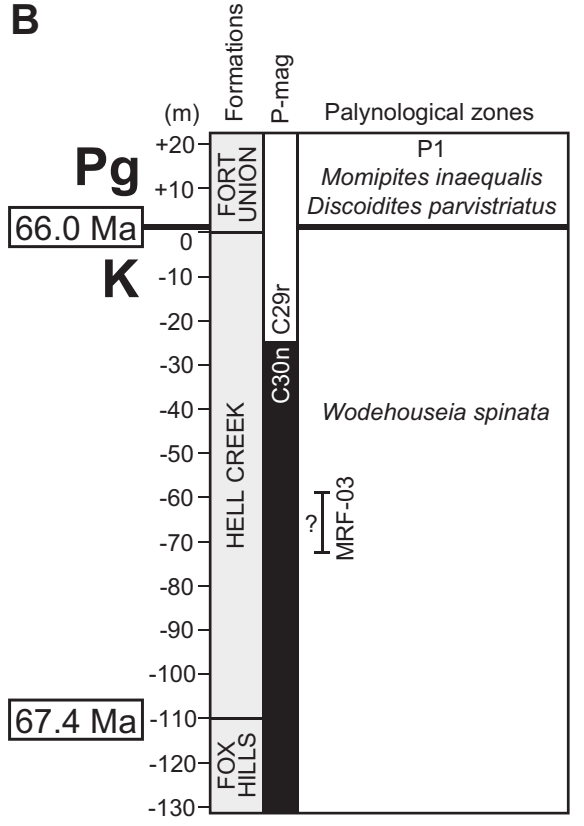

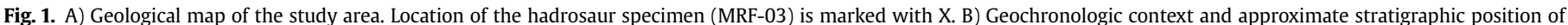
MRF-03 within the Hell Creek Formation.

preserved in siderite and manganese-rich calcium carbonate (Manning et al., 2009) and the specimen consists of an articulated individual, with three-dimensional integument (Fig. 2B) encasing at least one arm and hand, both feet, legs, and tail.

Within the latest Maastrichtian of North America, palynology has largely been used as a tool to help locate the CretaceousPaleogene $(\mathrm{K}-\mathrm{Pg})$ boundary. These results are outlined and summarized in Hartman et al., (2002), Nichols (2002, 2007), Nichols and Johnson (2008) and references therein, and more recently in Bercovici et al. (2009a, 2011, 2012). Herein we analyze the palynological assemblage of a fluvial sandstone, from the lower third of the Hell Creek Formation, encasing the exceptionally well preserved specimen of Edmontosaurus annectens (specimen MRF-03) with the specific aim of reconstructing the local vegetation and paleoenvironment of this particular site. This hadrosaur specimen was selected as it is extremely well-preserved (Manning et al., 2009), and thus represents a unique window in time for paleoenvironmental reconstruction.

\section{Geology and age}

Within the Western Interior Basin, the $\mathrm{K}-\mathrm{Pg}$ boundary has been identified at numerous sites from New Mexico to the Northwest Territories (Nichols and Johnson, 2008; Braman and Sweet, 2012 and very recently by Srivastava and Braman, 2013). occurring within magnetochron 29r (Lerbekmo et al., 1996). In North Dakota, South Dakota, and Montana, including where MRF-03 was found, the $\mathrm{K}-\mathrm{Pg}$ boundary occurs in close stratigraphical proximity with the formation contact between the Hell Creek Formation and the overlying Fort Union Formation (Fig. 1; Johnson et al., 2002; Nichols
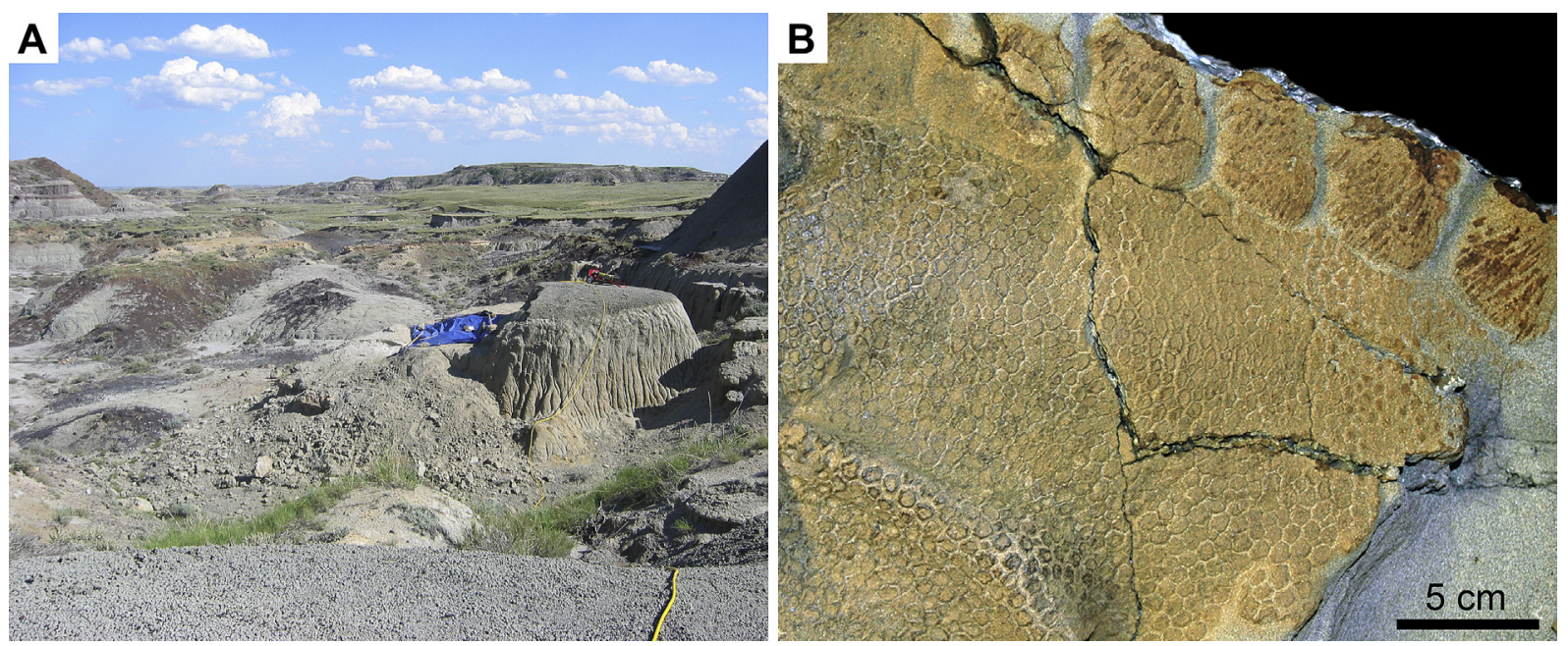

Fig. 2. A) Photograph of MRF-03 dig site and B) preservation of mineralized soft tissue. 
Table 1

General quantitative palynological data. Numbers represent the amount of taxa counted and percentage of each main group used in the palynological chart (Fig. 3 ) is also indicated.

\begin{tabular}{|c|c|}
\hline Taxa & Count \\
\hline Bryophytes & $4.0 \%$ \\
\hline Stereisporites spp. & 16 \\
\hline Ferns & $43.3 \%$ \\
\hline Azolla cretacea Stanley, 1965 & 1 \\
\hline Azolla microspores & 1 \\
\hline Cicatricosisporites spp. & 3 \\
\hline Cyathidites spp. & 68 \\
\hline Cyathidites australis Couper, 1953 & * \\
\hline $\begin{array}{l}\text { Cyathidites diaphana (Wilson and Webster, 1946) } \\
\text { Nichols and Brown, } 1992\end{array}$ & * \\
\hline Cyathidites minor Couper, 1953 & * \\
\hline Deltoidospora sp. & 18 \\
\hline Gleicheniidites spp. & 20 \\
\hline Laevigatosporites spp. & 58 \\
\hline $\begin{array}{l}\text { Laevigatosporites major (Cookson, 1947) } \\
\text { Krutzsch, } 1959\end{array}$ & * \\
\hline Laevigatosporites ovatus Wilson and Webster, 1946 & * \\
\hline Leptolepidites tenuis Stanley, 1965 & 2 \\
\hline Polycingulatisporites sp. & 1 \\
\hline Reticuloidosporites pseudomurii Elsik, 1968 & 1 \\
\hline Trilete spore sp. A & $*$ \\
\hline Trilete spore sp. B & $*$ \\
\hline Trilete spore sp. C & * \\
\hline \multicolumn{2}{|l|}{ Pteridosperms } \\
\hline Alisporites spp. & $*$ \\
\hline Alisporites cf. thomasii (Couper 1958) Nilsson 1958 & * \\
\hline Vitreisporites sp. & * \\
\hline Gymnosperms & $30.7 \%$ \\
\hline $\begin{array}{l}\text { Cerebropollenites macroverrucosus (Thiergart, 1949) } \\
\text { Pocock, } 1970\end{array}$ & $*$ \\
\hline Classopollis spp. & 1 \\
\hline Cycadopites spp. & 14 \\
\hline Cycadopites follicularis Wilson and Webster, 1946 & $*$ \\
\hline $\begin{array}{l}\text { Cycadopites granulatus (De Jersey, 1962) } \\
\text { De Jersey, } 1964\end{array}$ & $*$ \\
\hline $\begin{array}{l}\text { Ephedripites multipartitus (Chlonova, 1961) } \\
\text { Yu et al., } 1981\end{array}$ & 1 \\
\hline Bisaccates including: & 95 \\
\hline Piceapollis sp. & $*$ \\
\hline Pinuspollenites sp. & $*$ \\
\hline Pinuspollenites labdacus Potonié, 1958 & * \\
\hline Podocarpidites spp. & 1 \\
\hline Taxodiaceaepollenites spp. & 11 \\
\hline $\begin{array}{l}\text { Taxodiaceaepollenites hiatus (Potonié, 1932) } \\
\text { Kremp, } 1949\end{array}$ & * \\
\hline Dicotyledons & $16.5 \%$ \\
\hline Aquilapollenites attenuatus Funkhouser, 1961 & 1 \\
\hline Aquilapollenites catenireticulatus Srivastava, 1968 & $*$ \\
\hline $\begin{array}{l}\text { Aquilapollenites collaris (Tschudy and Leopold, 1971) } \\
\text { Nichols, } 1994\end{array}$ & * \\
\hline Aquilapollenites conatus Norton, 1965 & 2 \\
\hline $\begin{array}{l}\text { Aquilapollenites quadrilobus Srivastava and } \\
\text { Rouse, } 1970\end{array}$ & 1 \\
\hline Aquilapollenites reductus Norton, 1965 & 1 \\
\hline $\begin{array}{l}\text { Aquilapollenites senonicus (Mtchedlishvili, 1961) } \\
\text { Tschudy and Leopold, } 1971\end{array}$ & * \\
\hline Chenopodipollis sp. & 1 \\
\hline Ericipites sp. & $*$ \\
\hline $\begin{array}{l}\text { Kurtzipites circularis (Norton in Norton and } \\
\text { Hall, 1969) Srivastava, } 1981\end{array}$ & 1 \\
\hline Kurtzipites trispissatus Anderson, 1960 & 1 \\
\hline $\begin{array}{l}\text { Leptopecopites pocockii (Srivastava, 1967) } \\
\text { Srivastava, } 1978\end{array}$ & 2 \\
\hline Momipites inaequalis Anderson, 1960 & $*$ \\
\hline $\begin{array}{l}\text { Simplicepollis rallus (Stanley, 1965) } \\
\text { Nichols and Brown, } 1992\end{array}$ & 1 \\
\hline $\begin{array}{l}\text { Striatellipollis striatellus (Mtchedlishvili, 1961) } \\
\text { Krutzsch, } 1969\end{array}$ & 1 \\
\hline Tricolpites spp. & 4 \\
\hline Tricolpites microreticulatus Belsky et al., 1965 & 27 \\
\hline Triorites minor Couper, 1953 & $*$ \\
\hline Triporopollenites spp. & 20 \\
\hline
\end{tabular}

Table 1 (continued)

\begin{tabular}{ll}
\hline Taxa & Count \\
\hline Tschudypollis spp. & $*$ \\
Ulmipollenites krempii (Anderson, 1960) & 3 \\
Frederiksen, 1979 & $\mathbf{4 . 0 \%}$ \\
Algae & $*$ \\
Chomotriletes fragilis Pocock, 1962 & 2 \\
Pediastrum sp. & 14 \\
Schizophacus sp. & $*$ \\
Schizophacus laevigatus (Stanley, 1965) & \\
Nichols and Brown, 1992 & $*$ \\
Unidentified algal cyst & $\mathbf{1 . 5 \%}$ \\
Dinoflagellates & 6 \\
Dinoflagellates & Total \\
Total taxa: 60 & counted: 400 \\
\hline
\end{tabular}

and Johnson, 2008). It may locally be marked by a discontinuous but distinct $1 \mathrm{~cm}$-thick white layer containing the physical markers (i.e. shocked quartz and spherules) and the geochemical markers (i.e. Ir, Ni, Cr, Co anomalies) of the asteroid impact (Izett, 1990; Bohor, 1990; Ferrow et al., 2011) that formed the Chicxulub crater on the Yucatan platform 66.0 million years ago (Wigforss-Lange et al., 2007; Renne et al., 2013).

The study area was located on the western shore of the epicontinental Western Seaway (Sampson and Loewen, 2005; Braman and Sweet, 2012). The sedimentary succession as a whole consists of mudstones, siltstones and sandstones characteristic of terrestrial fluvio-deltaic deposits (Fig. 2A). Swampy environments characterized by peats were locally developed and there is also some evidence of brackish-water environments represented by the marine Breien Member of the Hell Creek Formation further east of the site of investigation (Murphy et al., 2002; Hoganson and Murphy, 2002). The thickness of the Hell Creek Formation in this area is about 110 meters and represents approximately 1.4 Myr in time (Fig. 1; Hicks et al., 2002).

\section{Material and methods}

The sandstone matrix immediately below the tail of the Edmontosaurus annectens specimen (MRF-03) was sampled for palynological analysis. The sample was processed according to standard palynological procedures at Global GeoLab Ltd, Canada. 20 grams of sandstone were first treated with dilute hydrochloric acid $(\mathrm{HCl})$ to remove calcium carbonate, and subsequently macerated by leaving the sample in $75 \%$ hydrofluoric acid (HF), followed by

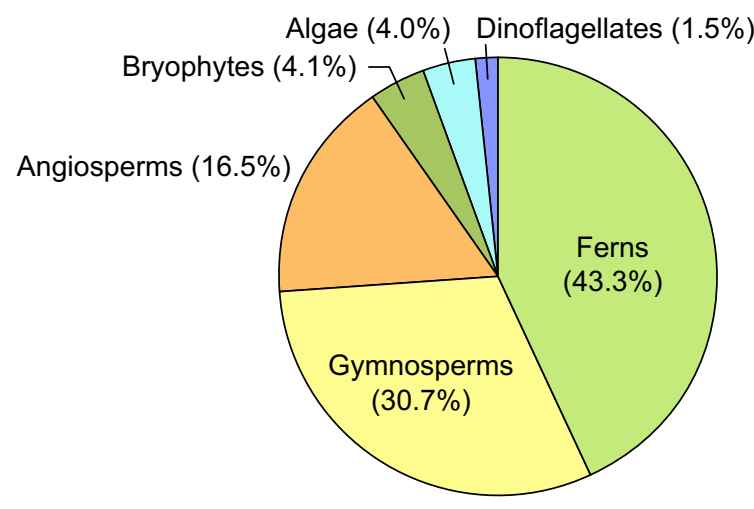

Fig. 3. Graphical representation of the percentages of palynomorphs. 
treatment in $\mathrm{HCl}$. One Lycopodium tablet (batch 1031, Department of Geology, Lund University) was added in order to calculate the recovery of organic particles per gram of sedimentary rock.

The organic residue was sieved using a $10 \mu \mathrm{m}$ mesh and mounted in epoxy resin on two microscopic slides. Four hundred palynomorphs were included in the quantitative analysis (Table 1;
Fig. 3) and two entire slides were thoroughly examined to check for the presence of remaining rare taxa (marked by ${ }^{*}$ in Table 1 ). A representative selection of palynomorphs was photographed and post-processed using extended depth of field reconstruction techniques (Bercovici et al., 2009b; Fig. 4). The palynofacies analysis involved counting the relative abundance of organic particles based
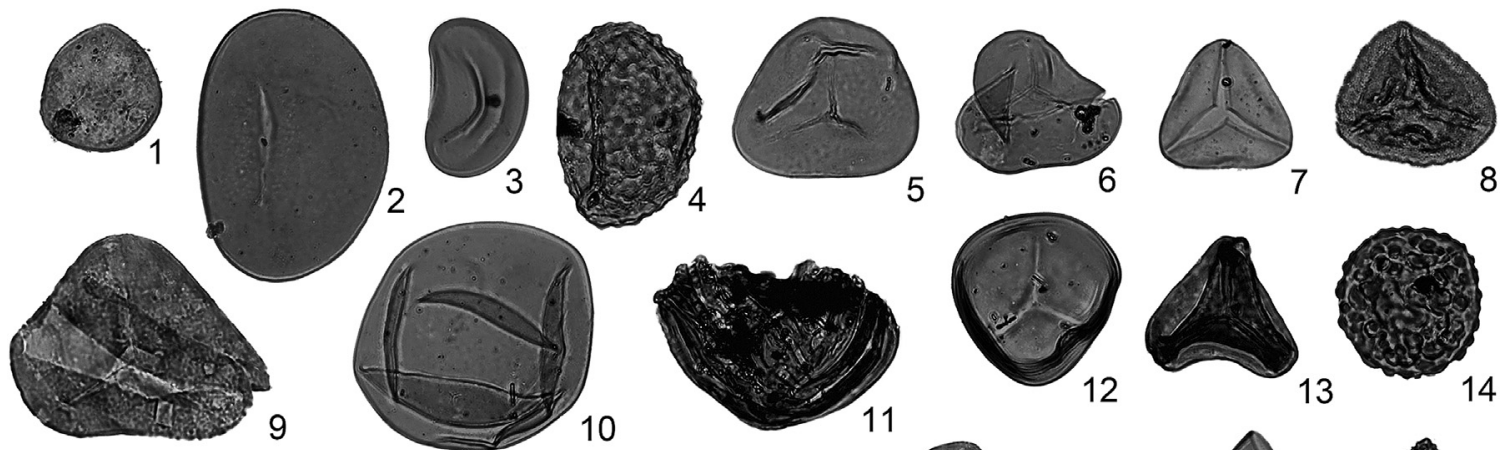

.
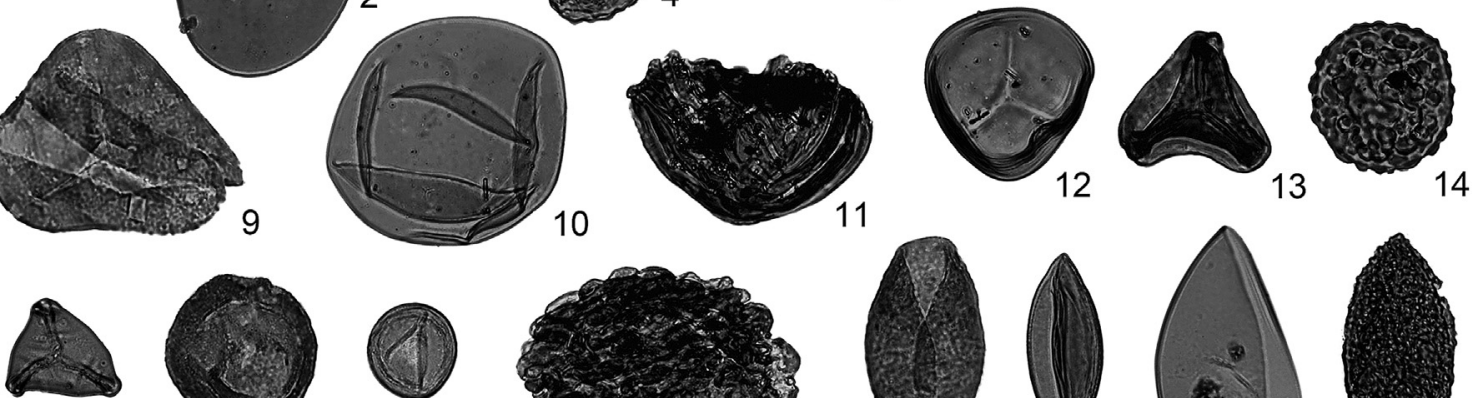

15
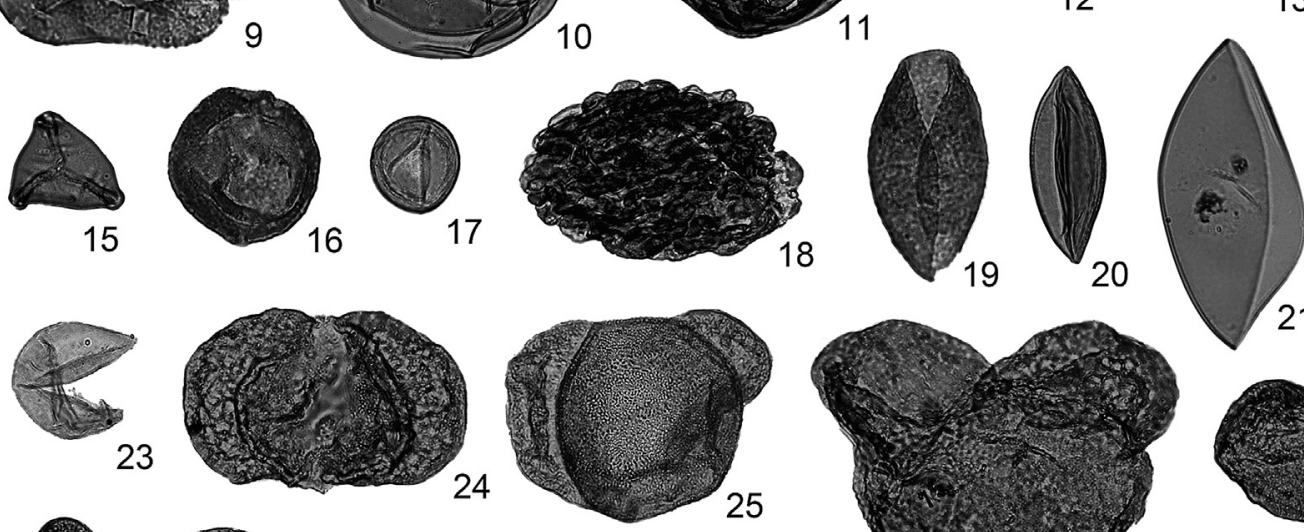

14

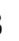
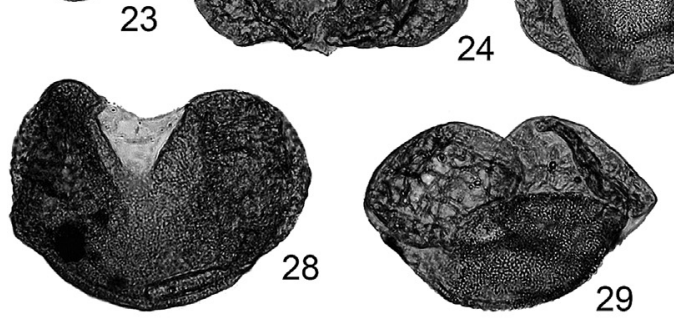

21
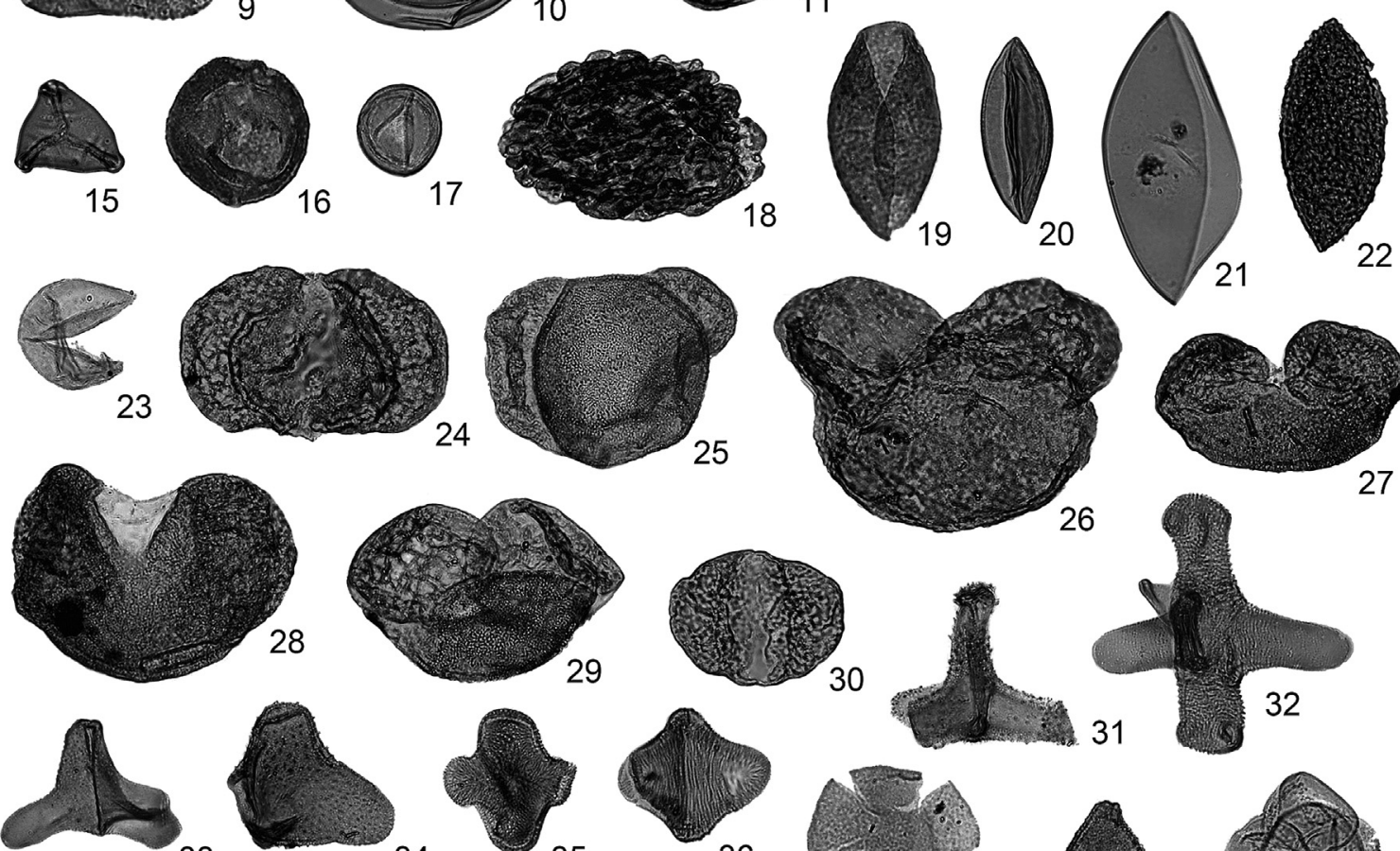

33

34
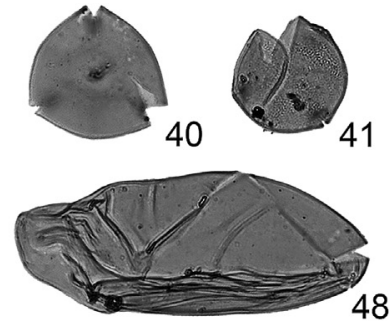

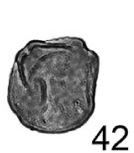

42

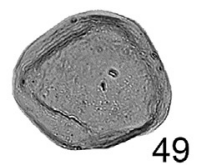

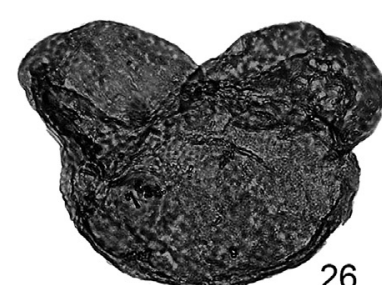

29

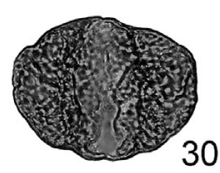

30

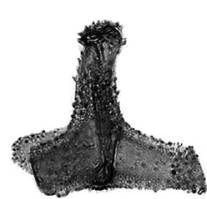

26
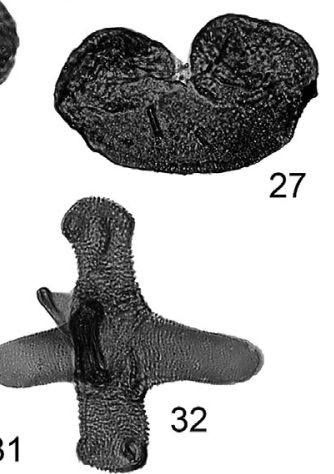
7

\section{2}

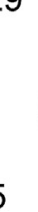

35

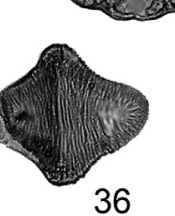

36

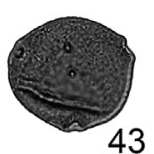

43

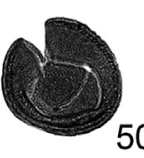

50

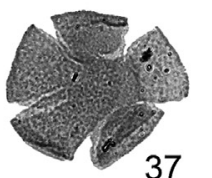

37

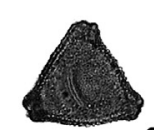

38

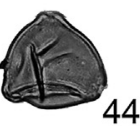

44

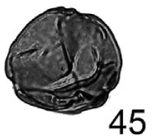

45
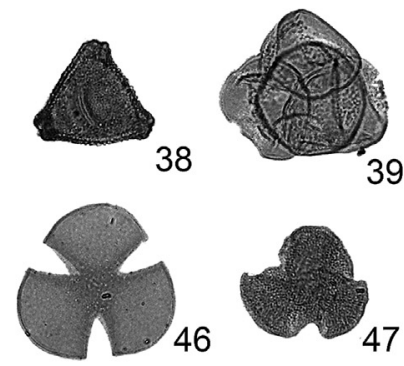

39

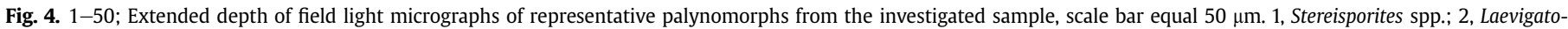

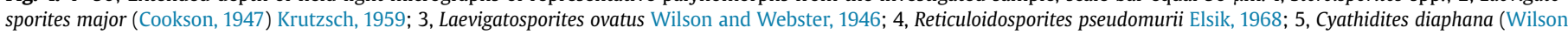

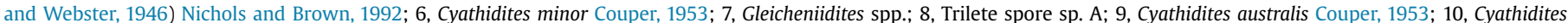

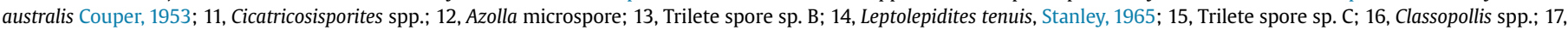

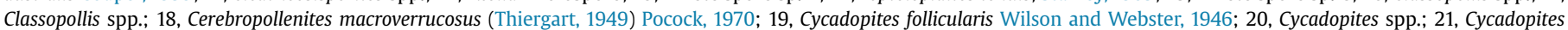

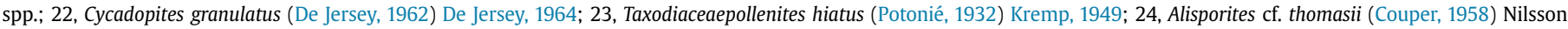

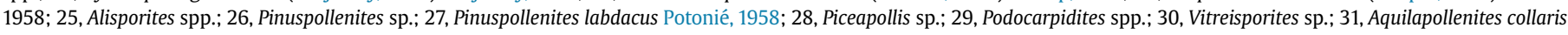

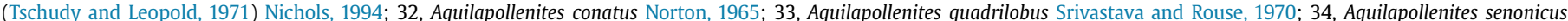

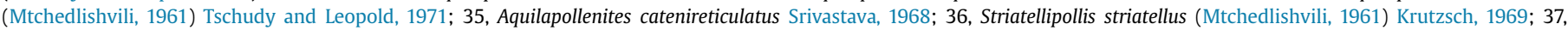

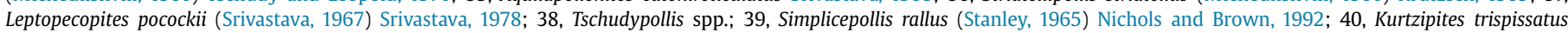

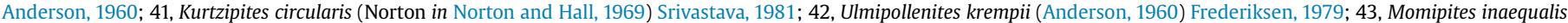

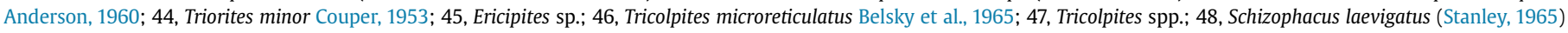
Nichols and Brown, 1992; 49, Freshwater algae; 50, Chomotriletes fragilis Pocock, 1962. 
A

\begin{tabular}{l|rrr} 
I: Palynomorphs & Count & Percent & Recov. /g \\
$\quad$ Pollen grains & 41 & $8.2 \%$ & 994 \\
$\quad$ Spores & 11 & $2.2 \%$ & 267 \\
II: SOM & 59 & $11.8 \%$ & 1430 \\
$\quad$ Black wood & 245 & $49.0 \%$ & 5939 \\
$\quad$ Brown wood & 46 & $9.2 \%$ & 1115 \\
\hline Charcoal & 17 & $3.4 \%$ & 412 \\
\hline Cuticles & 38 & $7.6 \%$ & 921 \\
$\quad$ Phytoclasts & 43 & $8.6 \%$ & 1042 \\
III: USTOM & 500 & & \\
Total & 43 & & \\
Lycopodium spores & & & \\
\end{tabular}

B

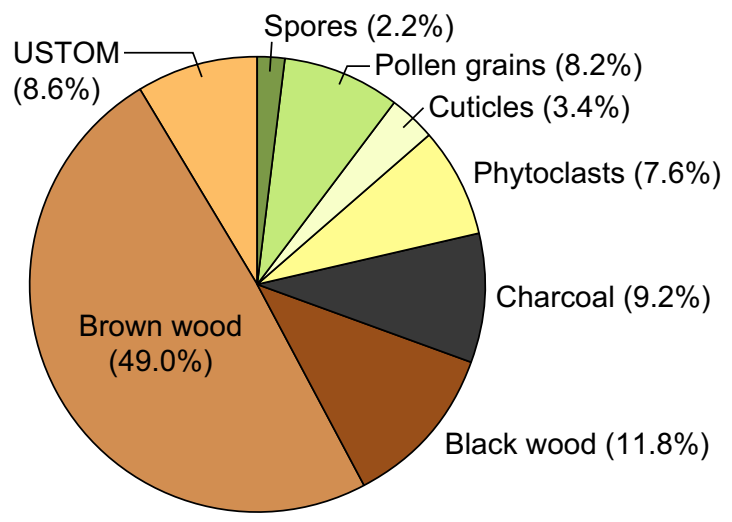

Fig. 5. Graphical representation of the percentages for each palynofacies categories (SOM: Structured organic matter, USTOM: Unstructured organic matter).

on 500 counts (Fig. 5). Classification of palynological matter was based on Batten's (1996) scheme adjusted to the local palynofacies, therefore not all sub-groups from Batten's classification system are represented within this study; (I) Palynomorphs-including the sub-categories; pollen, spores and dinoflagellates (II) Structured Organic Matter (SOM)-including the sub-categories; black wood, brown wood, charcoal, cuticles and phytoclasts. (III) Unstructured Organic Matter (USTOM). The slides are deposited in the Marmarth Research Foundation collections, USA.

\section{Results}

\subsection{Palynology}

The sample yielded a well-preserved palynoflora of medium diversity; 60 miospore taxa were identified (including 19 spore taxa, 3 seed fern taxa, 12 gymnosperm pollen taxa, 21 angiosperm pollen taxa and four taxa of algal cysts; Table 1). Additionally, six specimens of dinoflagellate cysts were recorded.

The ferns are chiefly represented by trilete spore taxa such as Cyathidites, Deltoidospora and Gleicheniidites spp. (ca. 27\% of total palynomorphs) followed by the monolete fern spore Laevigatosporites (14.5\%; Table 1). Conifers dominate the gymnospermous component, mainly represented by bisaccate pollen grains probably representing Pinaceae and seed-ferns (bisaccate pollen grains attributed to seedferns were recorded as part of the extended rare taxa count). Cycadopites pollen grains attain $4 \%$ of the total palynomorphs.

The angiosperm component is dominated by Tricolpites, together with a range of other tricolpate and triporate pollen types (Table 1). Biostratigraphically important taxa include Striatellipollis striatellus, Tricolpites microreticulatus, Leptopecopites pocockii and several species belonging to Aquilapollenites, collectively indicating a late Maastrichtian age.

\subsection{Palynofacies analysis}

The organic residue is heavily dominated by wood fragments (61\%) of which brown wood makes up the larger portion. Substantial amounts of charcoal are also present (9\%). Miospores (pollen + spores) constitute only $10 \%$ of the organic matter (Fig. 5). Dinoflagellates were not encountered within the count of 500 organic particles. Total number of organic particles per gram of sediments is calculated to 12,092 of which 1210 are miospores.

\section{Discussion and paleoenvironmental interpretation}

Dinosaurs with soft-tissue preservation are rare in the fossil record mainly due to bacterial decay and scavenging, but also due to damage by sedimentological processes where soft parts are destroyed prior to burial and fossilization (Briggs et al., 1997; Anderson et al., 1998; Bell, 2012). Most dinosaur skin impressions are incomplete, but in some cases reveal fine morphological details of the integument (Anderson et al., 1998; Bell, 2012). The hadrosaur specimen MRF-03 has the majority of its skin preserved three-dimensionally around the skeleton and thus provides additional insights into the soft tissue anatomy of Edmontosaurus annectens.

The completeness of the specimen indicates that it has not been subjected to any significant transport and the high fidelity preservation further indicates rapid post-mortem burial (Manning et al., 2009). Thus the palynomorphs preserved in the sediments encasing the hadrosaur reflect the regional vegetation at the immediate time of deposition (Fig. 6).

The pollen and spore record reveals diverse vegetation with elements of subtropical to warm-temperate forests dominated by ferns, with fewer gymnosperms. The ferns, which most likely grew on riverine flood plains, were mainly represented by plants related to modern Blechnum (Laevigatosporites), Osmundaceae (various trilete spore-taxa) and Gleicheniaceae (Gleicheniidites spp.) see Raine et al. (2011). Additionally, the presence of the water-fern Azolla indicates that this ecosystem incorporated mesothermal ponds or lakes (Vajda-Santivanez, 1999; Vajda and McLoughlin, 2005). The pollen signal indicates a canopy dominated by a range of evergreen needle trees producing bisaccate pollen grains (79\% out of gymnosperms) grains. It is difficult to identify the affinities of the plants producing the bisaccate pollen grains but Pinaceae, Podocarpaceae and seed-ferns (pteridosperms) are likely candidates. Alisporites-type pollen, probably produced by seed-ferns, constitutes a notable component of the bisaccate pollen group. Seed-ferns went extinct, together with over $75 \%$ of the global fauna and flora at the $\mathrm{K}-\mathrm{Pg}$ boundary event, except in southeastern Australia (including Tasmania) where one corystosperm and one bennettitalean lineage survived into the Paleogene (McLoughlin et al., 2008, 2011). Although seed ferns declined through the Cretaceous, Taylor et al. (2006) noted that Caytoniales (Sagenopteris) are recorded from several Upper Cretaceous sites of the Northern Hemisphere, including the USA, making this group a possible 


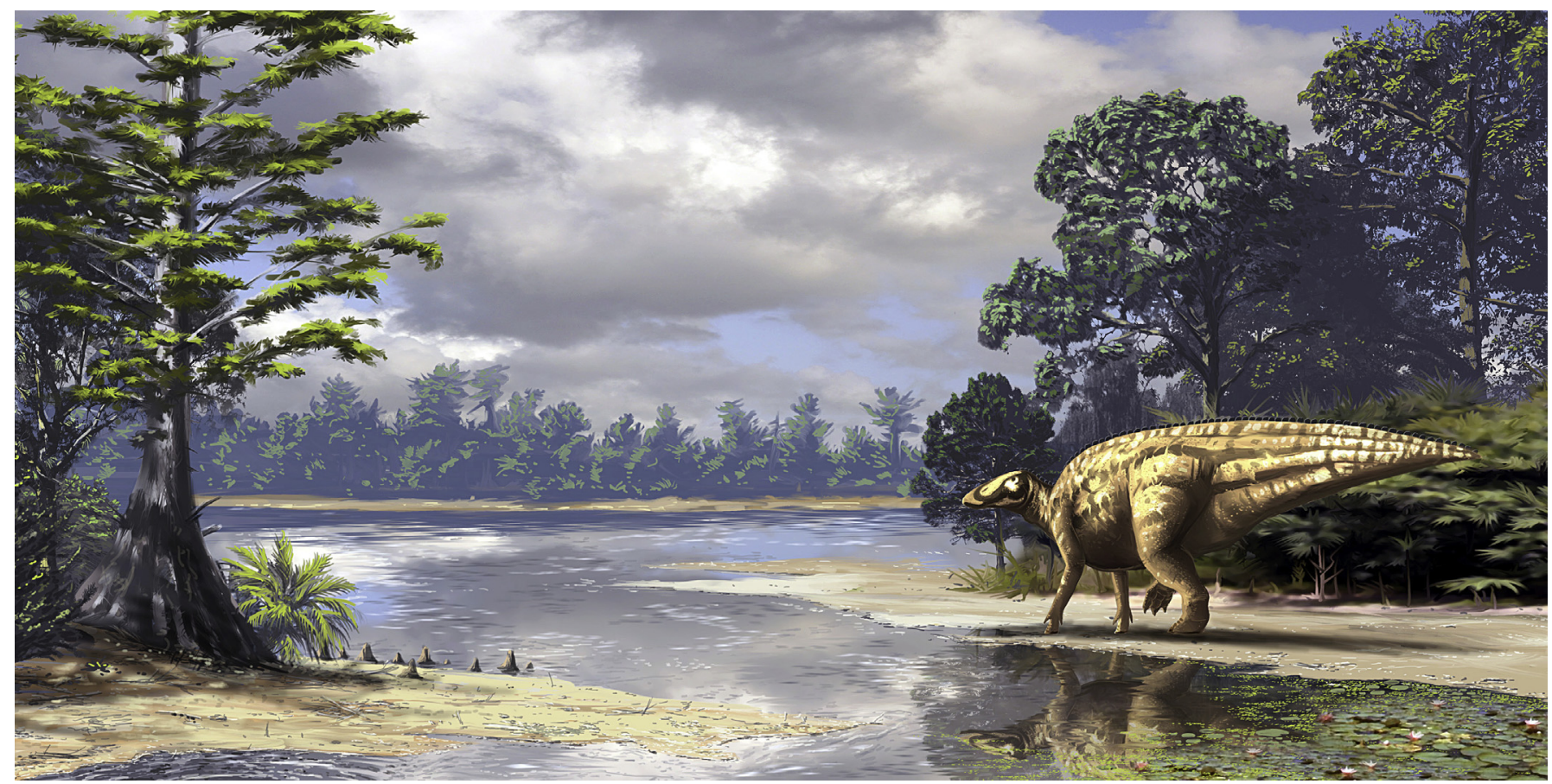

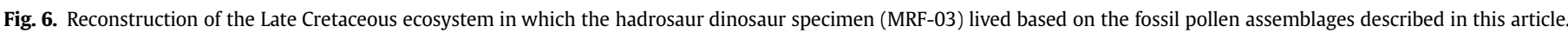
Artwork by Alain Bénéteau.

candidate for the Alisporites pollen detected in the palynological assemblage.

Other gymnosperms include cycads (11\% out of gymnosperms), and pollen produced by Taxodium and/or Glyptostrobus (9\% out of gymnosperms). The presence of Taxodium-related vegetation is further corroborated by e.g. macrofossils of Taxodium present in upper Maastrichtian deposits of the Fox Hill Formation, North Dakota (Peppe, 2003) and in Canadian deposits of the Edmonton Fm./Horseshoe Canyon Fm., pollen referable to those of Glyptostrobus, Sequoia and Taxodium have been reported (Srivastava, 1970) together with fossil taxodiaceous wood (Ramanujam and Stewart, 1969).

Plant groups producing monosulcate pollen include Ginkgo, cycads, and bennettites. Although bennettites have been encountered in the Maastrichtian of western North America (Stockey and Rothwell, 2003), they are generally sparse by the close of the Cretaceous and cycads are the most likely source of such pollen (Nichols and Johnson, 2008). This is further supported by results by Peppe (2003) who states that macrofossils of the cycad Nilssonia are strikingly common in the upper Maastrichtian Fox Hill Formation. Uncommon gymnosperm pollen taxa in the assemblage include Classopollis spp. produced by the important Mesozoic conifer Cheirolepidiaceae, which was a dominant component of Jurassic ecosystems (Jansson et al., 2008) and persisted so in South America through the Cretaceous (Barreda et al., 2012) but shows a declining importance to the end of the Cretaceous in North America and Europe (Axsmith et al., 2004; Axsmith and Jacobs, 2005; Traverse, 2007; Nichols and Johnson, 2008).

Flowering plants (angiosperms) were mostly represented by herbaceous forms. Tricolpites microreticulatus Belsky et al. (1965), which in the Southern Hemisphere is traditionally attributed to Gunnera (river pumpkin, wild rhubarb), dominates the angiosperm component in the studied sample.

It should however be pointed out that discrepancies exist between palynological and macrofloral assemblages in the fossil record and, in general, the pollen suggests a greater diversity of flora than that indicated by the macroflora, thus certain components are not represented in the macroflora assemblage (Pole and Vajda, 2009). Throughout the Hell Creek Formation, the angiosperms dominate in terms of diversity, representing over $86 \%$ of the macroflora (Johnson, 2002). This contrasts with the pollen and spore record which is instead dominated by fern spores and gymnosperm pollen (Fig. 3). This discrepancy may be explained by taphonomical and ecological biases, given that angiosperms can shed leaves seasonally in vast amounts while most conifers require more exceptional events such as heavy wind breaking of twigs and branches in order for them to make it into the macrofloral fossil record. Further, a substantial portion of the angiosperms were possibly insect pollinated thus producing considerably less pollen than the wind pollinated conifers. Accurate reconstruction of the local environment of MRF-03 requires contributions from both the macrofloral and the pollen record, considering that flowering plants are under-represented in the palynological record.

The palynofacies is characterized by a strong dominance of wood particles and scarcity of amorphous organic matter. This favors a high-energy, non-marine depositional setting such as a fluvial channel deposit, followed by rapid burial preventing further degradation. The dinosaur's presence within a sandstone channel deposit is congruent with the hypothesis that some hadrosaurs preferentially occupied environments proximal to river systems, whereas some other ornithischians, e.g., ceratopsian horned dinosaurs occupied drier parts of the associated floodplain (Lyson and Longrich, 2011).

Modern swamp environments host a broad range of communities including ponds, swamp cypress mires, and drier sites with Pinaceae woodlands (Richardson, 2010), containing taxa similar to the assemblage in the studied Hell Creek Formation. Furthermore, ponds in extant subtropical wetlands host notably different vegetation compared to the drier flood plain assemblages. The ponds support a broad range of aquatic angiosperms, e.g., Nymphaea (water lily), fresh-water algae and aquatic ferns, such as Azolla (Richardson, 2010). The presence of Azolla and non-marine 
algae such as Pediastrum in the Hell Creek Formation flora offers additional support for this environmental analogy. We propose subtropical swamps as a modern analog for the Late Cretaceous ecosystem studied herein. The presence of a few specimens of dinoflagellate cysts indicates episodic marine influence. Our interpretation of a sub-tropical swamp setting for the studied assemblage is consistent with paleoenvironmental reconstructions for the upper part of the Horseshoe Canyon Formation in Canada, roughly coeval with the Hell Creek Formation (Eberth and Currie, 2010) for which a warm and wet alluvialpaludal setting with meandering channels and extensive wetlands has been inferred (Eberth and Braman, 2012).

The pineland communities in some modern wetlands have evolved adaptations that both promote and resist fire, as these trees need fire to regenerate (Richardson, 2010). It is possible that fire was also a driving force behind the proliferation of several gymnosperm and pteridophyte groups in the Hell Creek ecosystem, as the occurrence of charcoal in the palynological residues reveals that wildfires were part of this Late Cretaceous ecosystem.

\section{Conclusions}

A palynological analysis of the sandstone matrix encasing the hadrosaur MRF-03 from the Hell Creek Formation reveals a wellpreserved late Maastrichtian miospore assemblage. The vegetation forming the coastal plain ecosystem that the hadrosaur inhabited, constituted a forest with a canopy of evergreen conifers, mainly pines but with Taxodium and cycads as additional elements. Ferns and herbaceous angiosperms grew in the undercover, providing a prime food-source for the Late Cretaceous herbivorous dinosaurs of the Hell Creek area. Based on the high abundance of terrestrial palynomorphs, together with the low abundance of fresh-brackish water algae, this analysis indicates deposition in a relatively high-energy delta plain to estuarine environment, where components from the nearby mire ecosystems are incorporated in the assemblages.

The presence of charcoal indicates that wildfires were relatively common in the Hell Creek ecosystem.

\section{Acknowledgments}

We thank landowners M. and J. Sonsalla for donating the material to the Marmarth Research Foundation. This material is based on work supported by the Royal Swedish Academy of Sciences Research Fellow funded through the Knut and Alice Wallenberg Foundation (to V.Vajda), the Swedish Research Council through Linnaeus grant (LUCCI) to V. Vajda and A. Bercovici. T.R. Lyson was supported by a Smithsonian Institution Peter Buck Postdoctoral Fellowship. A. Bercovici is supported through the Swedish Research Council (VR) postdoctoral fellowship grant 2011-7176. Two anonymous reviewers are thanked for constructive criticism that greatlyimproved this paper. Russ Harms, Global Geolab Ltd. is thanked for palynological processing.

\section{References}

Anderson, R.Y., 1960. Cretaceous-Tertiary palynology, eastern side of the San Juan Basin, New Mexico. New Mexico Institute of Mining and Technology Memoir 6 , 59.

Anderson, B.G., Lucas, S.G., Barrick, R.B., Heckert, A.B., Basabilvazo, T.G., 1998 Dinosaur skin impressions and associated skeletal remains from the upper Campanian of southwestern New Mexico: new data on the integument morphology of hadrosaurs. Journal of Vertebrate Paleontology 18, 739-745.

Axsmith, B.J., Jacobs, B.F., 2005. The conifer Frenelopsis ramosissima (Cheirolepidiaceae) in the Lower Cretaceous of Texas: systematic, biogeographical, and paleoecological implications. International Journal of Plant Sciences 166, 327-337.
Axsmith, B.J., Krings, M., Waselkov, K., 2004. Conifer pollen cones from the Cretaceous of Arkansas: Implications for diversity and reproduction in the Cheirolepidiaceae. Journal of Paleontology 78, 402-409.

Barreda, V.D., Cúneo, N.R., Wilf, P., Currano, E.D., Scasso, R.A., Brinkhuis, H., 2012 Cretaceous/Paleogene floral turnover in Patagonia: Drop in diversity, low extinction, and a Classopollis spike. PLoS ONE 7, 8.

Batten, D.J., 1996. Palynofacies and palaeoenvironmental interpretation. Chapter 26A. In: Jansonius, J., McGregor, D.C. (Eds.), Palynology: Principles and Applications 3. American Association of Stratigraphic Palynologists Foundation, Dallas, pp. 1011-1164.

Bell, P.R., 2012. Standard terminology and potential taxonomic utility for hadrosaurid skin impressions: A case study for Saurolophus from Canada and Mongolia. PLoS ONE 7 (2), e31295. http://dx.doi.org/10.1371/journal.pone.0031295.

Belsky, C.Y., Boltenhagen, E., Potonié, R., 1965. Sporae dispersae der Oberen Kreide von Gabun, Äquatoriales Afrika. Paläontologische Zeitschrift 39 $72-83$.

Bercovici, A., Pearson, D.A., Nichols, D.J., Wood, J., 2009a. Biostratigraphy of selected K/T boundary sections in southwestern North Dakota, USA: toward a refinement of palynological identification criteria. Cretaceous Research 30, 632-658.

Bercovici, A., Hadley, A., Villanueva-Amadoz, U., 2009b. Improving depth of field resolution for palynological photomicrography. Paleontologia Electronica. PE Article Number: 12.2.5T, pp. 12.

Bercovici, A., Vajda, V., Pearson, D., Villanueva-Amadoz, U., Kline, D., 2011. Palynostratigraphy of John's Nose, a new Cretaceous-Paleogene boundary section in southwestern North Dakota, USA. Palynology 36, 36-47.

Bercovici, A., Vajda, V., Sweet, A., 2012. Pollen and spore stratigraphy of the Cretaceous-Paleogene mass-extinction interval in the Northern Hemisphere. Journal of Stratigraphy 36, 165-178.

Bohor, B.F., 1990. Shock-induced microdeformation in quartz and other mineralogical indications of an impact event at the Cretaceous/Tertiary boundary. Tectonophysics 171, 359-372.

Braman, D.R., Sweet, A.R., 2012. Biostratigraphically useful Late CretaceousPaleocene terrestrial palynomorphs from the Canadian Western Interior Sedimentary Basin. Palynology 36, 8-35.

Briggs, D.E.G., Wilby, P.R., Perez-Moreno, B.P., Sanz, J.L., Freganal-Martinez, M. 1997. The mineralization of dinosaur soft tissue in the Lower Cretaceous of Las Hoyas, Spain. Journal of the Geological Society of London 154, $587-$ 588 .

Campione, N.E., Evans, D.C., 2011. Cranial growth and variation in Edmontosaurs (Dinosauria: Hadrosauridae): Implications for latest Cretaceous megaherbivore diversity in North America. PLoS ONE 6 (9), e25186. doi:10.1371.

Chlonova, A.F., 1961. Spores and pollen of the upper half of the Upper Cretaceous of the eastern part of the West Siberian lowland. Academy of Sciences of the U.S.S.R. (Siberian Branch), Institute of Geology and Geophysics, Trudy 7, 138 [Russian].

Cookson, I.C., 1947. Plant microfossils from the lignites of Kerguelen Archipelago. British-Australian-New Zealand Antarctic Research Expedition, 1929-31 Reports. Series A 2, 129-142.

Couper, R.A., 1953. Upper Mesozoic and Cainozoic spores and pollen grains from New Zealand. New Zealand Geological Survey Paleontological Bulletin 22, 77.

Couper, R.A., 1958. British Mesozoic microspores and pollen grains. Palaeontographica Abt. B 103, 75-179.

Chin, K., Pearson, D.A., Ekdale, A.A., 2013. Fossil worm burrows reveal very early terrestrial animal activity and shed light on trophic resources after the endCretaceous mass extinction. PLoS ONE 8 (8), 8 e70920 http://dx.doi.org/10.1371/ journal.pone.0070920.

De Jersey, N.J., 1962. Triassic spores and pollen grains from the Ipswich coalfield. Geological Survey of Queensland, Publication 307, pp. 1-18.

De Jersey, N.J., 1964. Triassic spores and pollen grains from the Bundamba group. Geological Survey of Queensland, Publication 321, pp. 1-21.

Eberth, D.A., Braman, D.R., 2012. A revised stratigraphy and depositional history for the Horseshoe Canyon Formation (Upper Cretaceous), southern Alberta plains. Canadian Journal of Earth Sciences 49, 1053-1086.

Eberth, D.A., Currie, P.J., 2010. Stratigraphy, sedimentology and taphonomy of the Albertosaurus bonebed (upper Horseshoe Canyon Formation; Maastrichtian), southern Alberta, Canada. Canadian Journal of Earth Sciences 47 $1119-1143$.

Elsik, W.C., 1968. Palynology of a Paleocene Rockdale lignite, Milam County, Texas. 1. Morphology and taxonomy. Pollen et Spores 10, 263-314.

Ferrow, E., Vajda, V., Bender Koch, C., Peucker-Ehrenbrink, B., Willumsen, P., 2011. Multiproxy analysis of a new terrestrial and a marine Cretaceous-Paleogene (K$\mathrm{Pg}$ ) boundary site from New Zealand. Geochimica et Cosmochimica Acta 75, 657-672.

Frederiksen, N.O., 1979. Paleogene sporomorph biostratigraphy, northeastern Virginia. Palynology 3, 129-167.

Funkhouser, J.W., 1961. Pollen of the genus Aquilapollenites. Micropaleontology 7, 193-198.

Hartman, J.H., Johnson, K.R., Nichols, D.J. (Eds.), 2002. The Hell Creek Formation and the Cretaceous-Tertiary boundary in the Northern Great Plains: an integrated Continental Record of the End of the Cretaceous. Geological Society of America Special Paper 361, 526 pp.

Hoganson, J.W., Murphy, E.C., 2002. Marine Breien Member (Maastrichtian) of the Hell Creek Formation in North Dakota: Stratigraphy, vertebrate fossil record, 
and age. In: Hartman, J.H., Johnson, K.R., Nichols, D.J. (Eds.), The Hell Creek Formation and the Cretaceous-Tertiary boundary in the Northern Great Plains: an Integrated Continental Record of the End of the Cretaceous, Geological Society of America Special Paper 361, Boulder Colorado, pp. 247-270.

Hicks, J.F., Johnson, K.R., Obramovich, J.D., Tauxe, L., Clark, D., 2002. Magnetostratigraphy and geochronology of the Hell Creek and basal Fort Union Formations of southwestern North Dakota and a recalibration of the age of the Cretaceous-Tertiary boundary. In: Hartman, J.H., Johnson, K.R., Nichols, D.J. (Eds.), The Hell Creek Formation and the Cretaceous-Tertiary boundary in the Northern Great Plains: an Integrated Continental Record of the End of the Cretaceous, Geological Society of America Special Paper 361, Boulder Colorado, pp. $574-585$.

Izett, G.A., 1990. The Cretaceous/Tertiary boundary interval, Raton Basin, Colorado and New Mexico, and its content of shock-metamorphosed minerals: evidence relevant to the K-T boundary impact-extinction theory. Geological Society of America Special Paper 249, Boulder Colorado, 100 pp.

Jansson, I.-M., McLoughlin, S., Vajda, V., Pole, M., 2008. An Early Jurassic flora from the Clarence-Moreton Basin, Australia. Review of Palaeobotany and Palynology $150,5-21$.

Johnson, K.R., 2002. Megaflora of the Hell Creek and lower Fort Union formations in the western Dakotas: vegetational response to climate change, the CretaceousTertiary boundary event, and rapid marine transgression. In: Hartman, J.H. Johnson, K.R., Nichols, D.J. (Eds.), The Hell Creek Formation and the CretaceousTertiary boundary in the Northern Great Plains: an Integrated Continental Record of the End of the Cretaceous, Geological Society of America Special Paper 361, Boulder Colorado, pp. 329-391.

Johnson, K.R., Nichols, D.J., Hartman, J.H., 2002. Hell Creek Formation: A synthesis. In: Hartman, J.H., Johnson, K.R., Nichols, D.J. (Eds.), The Hell Creek Formation and the Cretaceous-Tertiary boundary in the Northern Great Plains: an Integrated Continental Record of the End of the Cretaceous, Geological Society of America Special Paper 361, Boulder Colorado, pp. 503-510.

Kremp, G.O.W., 1949. Pollenanalytische Untersuchung des miozänen Braunkohlenlagers von Konin an der Warthe. Palaeontographica Abt. B 90, 53-93.

Krutzsch, W., 1959. Mikropaläontologische (sporenpaläontologische) Untersuchungen in der Braunkohle des Geiseltales. Geologie 8 (21/22), 425 pp.

Krutzsch, W., 1969. Taxonomie syncolp(or)ater und morphologisch benachbarter Pollengattungen und -arten (Sporae dispersae) aus der Oberkreide und dem Tertiär, Teil I: Syncolp(or)ate und syncolp(or)atoide. Pollen et Spores 11, $397-424$.

Lerbekmo, J.F., Sweet, A.R., Duke, M.J.M., 1996. A normal polarity subchron that embraces the K/T boundary: a measure of sedimentary continuity across the boundary and synchroneity of boundary events. In: Ryder, G., Fastovsky, D., Gartner, S. (Eds.), The Cretaceous-Tertiary event and other catastrophes in earth history, Geological Society of America Special Paper 307, Boulder Colorado, pp. 465-476.

Lyson, T.R., Longrich, N.R., 2011. Spatial niche partitioning in dinosaurs from the latest Cretaceous (Maastrichtian) of North America. Proceedings of the Roya Society B 278, 1158-1164.

Lyson, T.R., Bercovici, A., Chester, S.G.B., Sargis, E.J., Pearson, D.A., Joyce, W.G., 2012 Dinosaur extinction: closing the "3 $\mathrm{m}$ gap". Biology Letters 7, 925-928.

Manning, P.L., Morris, P.M., McMahon, A., Jones, E., Gize, A., Macquaker, J.H.S., Wolff, G., Thompson, A., Marshall, J., Taylor, K.G., Lyson, T., Gaskell, S. Reamtong, O., Sellers, W.I., van Dongen, B.E., Buckley, M., Wogelius, R.A., 2009. Mineralized soft-tissue structure and chemistry in a mummified hadrosaur from the Hell Creek Formation, North Dakota (USA). Proceedings of the Roya Society B, 3429-3437.

McLoughlin, S., Carpenter, R.J., Jordan, G.J., Hill, R.S., 2008. Seed ferns survived the end-Cretaceous mass extinction in Tasmania. American Journal of Botany 95, 465-471.

McLoughlin, S., Carpenter, R.J., Pott, C., 2011. Ptilophyllum muelleri (Ettingsh.) comb. nov. from the Oligocene of Australia: Last of the Bennettitales? International Journal of Plant Sciences 172, 574-585.

Mtchedlishvili, N.D., 1961. Palynological characteristic of the Cretaceous sediments of the West-Siberian depression (Cenomanian, Turonian, Danian). In Samoilovitch, S.R. (Ed.), Pollen and Spores of Western Siberia. Trudy Vsesoyuznyy Nauchno-Issledovatel'skiy Geologorazvedochniy Neftyanoy Institut (VNIGRI) (in Russian), 177, 291-298 and 329-332.

Murphy, E.D., Hoganson, J.W., Johnson, K.R., 2002. Lithostratigraphy of the Hell Creek Formation in North Dakota. In: Hartman, J.H., Johnson, K.R., Nichols, D.J. (Eds.), The Hell Creek Formation and the Cretaceous-Tertiary boundary in the Northern Great Plains: an Integrated Continental Record of the End of the Cretaceous, Geological Society of America Special Paper 361, Boulder Colorado, pp. 9-34.

Nichols, D.J., 1994. A revised palynostratigraphic zonation of the nonmarine Upper Cretaceous, Rocky Mountain region, United States. In: Caputo, M.V. Peterson, J.A., Franczyk, K.J. (Eds.), Mesozoic systems of the Rocky Mountain region, USA. SEPM (Society for Sedimentary Geology), Rocky Mountain Section, Denver Colorado, pp. 503-521.

Nichols, D.J., 2002. Palynology and palynostratigraphy of the Hell Creek Formation in North Dakota: A microfossil record of plants at the end of Cretaceous time. In: Hartman, J.H., Johnson, K.R., Nichols, D.J. (Eds.), The Hell Creek Formation and the Cretaceous-Tertiary boundary in the Northern Great Plains: an Integrated Continental Record of the End of the Cretaceous, Geological Society of America Special Paper 361, Boulder Colorado, pp. 393-456.
Nichols, D.J., 2007. Selected plant-microfossil records of the terminal Cretaceous event in terrestrial rocks, western North America. Palaeogeography, Palaeoclimatology, Palaeoecology 255, 22-34.

Nichols, D.J., Brown, J.L., 1992. Palynostratigraphy of the Tullock Member (lower Paleocene) of the Fort Union Formation in the Powder River Basin, Montana and Wyoming. U.S. Geological Survey Bulletin 1917-F, 35.

Nichols, D.J., Johnson, K.R., 2008. Plants and the K-T Boundary. Cambridge University Press, $280 \mathrm{pp}$.

Norton, N.J., 1965. Three new species of Aquilapollenites from the Hell Creek Formation, Garfield County, Montana. Pollen et Spores 7, 135-143.

Norton, N.J., Hall, J.W., 1969. Palynology of the Upper Cretaceous and lower Tertiary in the type locality of the Hell Creek Formation, Montana, U.S.A. Palaeontographica Abt. B 125, 1-64.

Ocampo, A., Vajda, V., Buffetaut, E., 2006. Unravelling the Cretaceous-Paleogene (KT) catastrophe: Evidence from flora fauna and geology. In: Cockell, C., Koeberl, C., Gilmour, I. (Eds.), Biological Processes Associated with Impact Events. Springer-Verlag series, pp. 203-227.

Pearson, D.A., Schaefer, T., Johnson, K.R., Nichols, D.J., 2001. Palynologically calibrated vertebrate record from North Dakota consistent with abrupt dinosaur extinction at the Cretaceous-Tertiary boundary. Geology 29, 39-42.

Pearson, D.A., Schaefer, T., Johnson, K.R., Nichols, D.J., Hunter, J.P., 2002. Vertebrate biostratigraphy of the Hell Creek Formation in southwestern North Dakota and northwestern South Dakota. In: Hartman, J.H., Johnson, K.R., Nichols, D.J. (Eds.), The Hell Creek Formation and the Cretaceous-Tertiary boundary in the Northern Great Plains: an Integrated Continental Record of the End of the Cretaceous, Geological Society of America Special Paper 361, Boulder Colorado, pp. 145-167.

Peppe, D.J., 2003. Fox Hills I, a new upper Maastrichtian megafloral zone within the Williston Basin of North Dakota. Bachelors Thesis. Department of Geology of St. Lawrence University, Canton, New York, 155 pp.

Pocock, S.A.J., 1962. Microfloral analysis and age determination of strata at the Jurassic-Cretaceous boundary in the western Canada plains. Palaeontographica Abt. B 111 (1-3), 1-96.

Pocock, S.A.J., 1970. Palynology of the Jurassic sediments of Western Canada. Palaeontographica Abt. B 130 (3-6), 12-72.

Pole, M., Vajda, V., 2009. A new terrestrial Cretaceous-Paleogene site in New Zealand - turnover in macroflora confirmed by palynology. Cretaceous Research 30, 917-938.

Potonié, R., 1932. Pollenformen aus tertiären Braunkohlen. Jahrbuch der Preussischen Geologischen Landesanstalt 52,1-7.

Potonié, R., 1958. Synopsis der Gattungen der Sporae dispersae, 2 Teil: Sporites (Nachträge), Saccites, Aletes, Praecolpates, Polyplicates, Monocolpates. Beihefte zum Geologischen Jahrbuch 31, 114 pp.

Raine, J.I., Mildenhall, D.C., Kennedy, E.M., 2011. New Zealand fossil spores and pollen: an illustrated catalogue, 4th edition. In: GNS Science miscellaneous series no. 4. http://data.gns.cri.nz/sporepollen/index.htm.

Ramanujam, C.G.K., Stewart, W.N., 1969. Fossil woods of Taxodiaceae from the Edmonton Formation (Upper Cretaceous) of Alberta. Canadian Journal of Botany 47, $115-124$

Renne, P.R., Deino, A.L., Hilgen, F.J., Kuiper, K.F., Mark, D.F., Mitchell, W.S., Morgan, L.E., Mundil, R., Smit, J., 2013. Time scales of critical events around the Cretaceous-Paleogene boundary. Science 339, 684-687.

Richardson, C.J., 2010. The Everglades: North America's subtropical wetland. Wetlands Ecology and Management 18, 517-542.

Sampson, S.D., Loewen, M.A., 2005. Tyrannosaurus rex from the Upper Cretaceous (Maastrichtian) North Horn Formation of Utah: biogeographic and paleoecologic implications. Journal of Vertebrate Paleontology 25, 469-472.

Srivastava, S.K., 1967. Palynology of Late Cretaceous mammal beds, Scollard, Alberta (Canada). Palaeogeography, Palaeoclimatology, Palaeoecology 3 (1), 133-150.

Srivastava, S.K., 1968. Reticulate species of Aquilapollenites and emendation of the genus Mancicorpus Mchedlishvili. Pollen et Spores 10, 665-699.

Srivastava, S., 1970. Pollen biostratigraphy and paleoecology of the Edmonton Formation (Maestrichtian), Alberta, Canada. Palaeogeography, Palaeoclimatology, Palaeoecology 7, 221-276.

Srivastava, S.K. 1978. Leptopecopites, a new genus from the Canadian Maastrichtian. Pollen et Spores 20, 555-568.

Srivastava, S.K., 1981. Fossil pollen genus Kurtzipites Anderson. Journal of Paleontology 55, 868-879.

Srivastava, S.K., Braman, D.R., 2013. The palynostratigraphy of the Edmonton Group (Upper Cretaceous) of Alberta, Canada. Palynology 37, 1-27.

Srivastava, S.K., Rouse, G.E., 1970. Systematic revision of Aquilapollenites Rouse 1957. Canadian Journal of Botany 48, 1591-1601.

Stanley, E.A., 1965. Upper Cretaceous and Paleocene plant microfossils and Paleocene dinoflagellates and hystrichosphaerids from northwestern South Dakota. American Paleontology Bulletins 49, 177-384.

Stockey, R.A., Rothwell, G.W., 2003. Anatomically preserved Williamsonia (Williamsoniaceae): Evidence for Bennettitalean reproduction in the Late Cretaceous of Western North America. International Journal of Plant Sciences 164, $251-262$.

Taylor, E.L., Taylor, T.N., Kerp, H., Hermsen, E.J., 2006. Mesozoic seed ferns: Old paradigms, new discoveries. Journal of the Torrey Botanical Society 133, 62-82. Traverse, A., 2007. Paleopalynology. Springer, 814 pp.

Thiergart, F., 1949. Der stratigraphische Wert mesozoischer Pollen und Sporen. Palaeontographica Abt. B 89, 1-34. 
Tschudy, B.D., Leopold, E.B., 1971. Aquilapollenites (Rouse) Funkhouser - Selected Rocky Mountain taxa and their stratigraphic ranges. In: Kosanke, R.M., Cross, A.T. (Eds.), Symposium on palynology of the Late Cretaceous and early Tertiary, Geological Society of America Special Paper 127, Boulder Colorado, pp. 113-167. Vajda, V., McLoughlin, S., 2005. A new Maastrichtian-Paleocene Azolla species from Bolivia, with a comparison of the global record of coeval Azolla microfossils. Alcheringa 29, 305-329.

Vajda, V., Raine, J.I., Hollis, C., 2001. Indication of global deforestation at the CretaceousTertiary boundary by New Zealand fern spike. Science 294, 1700-1702.

Vajda, V., Raine, I.J., Hollis, C.J., Strong, C.P., 2004. Global effects of the Chicxulub Impact on Terrestrial Vegetation - review of the palynological record from New Zealand Cretaceous/Tertiary Boundary. Impact into Marine and Icy Environments, pp. 57-74.
Wigforss-Lange, J., Vajda, V., Ocampo, A., 2007. Trace element concentrations in the Mexico-Belize ejecta layer: A link between the Chicxulub impact and the global Cretaceous-Paleogene boundary. Meteoritics and Planetary Science 42, $1871-1882$.

Vajda-Santivanez, V., 1999. Miospores from upper cretaceous-Paleocene Strata in Northwestern Bolivia. Palynology 23, 181-196.

Wilson, L.R., Webster, R.M., 1946. Plant microfossils from a Fort Union coal of Montana. American Journal of Botany 33, 271-278.

Yu, J., Guo, Z. Mao, S., 1981. Cretaceous palynological assemblages from the district south of the Songhua River, in assemblage of Late Cretaceous sporo-pollens in the Songhua Jiang-Liao He Basin. Daqing Oil Field Development Research Institute Professional Papers on Stratigraphy and Paleontology [Chinese], pp. 1-117. 